\title{
Influence of bromopride in the prophylaxis of nausea associated with fluorescein angiography
}

\author{
Influência da bromoprida na profilaxia de ná useas na angiofluoresceinografia
}

\author{
Rodrigo Pessoa Cavalcanti Lira ${ }^{1}$ \\ Luiz Felipe Lynch de Moraes $^{2}$ \\ Mauro de Oliveira Júnior ${ }^{3}$ \\ Antônio Luiz Barbosa de Melo ${ }^{4}$ \\ Mirelle Souza Leão Vasconcelos ${ }^{5}$
}

\begin{tabular}{l} 
ABSTRACT \\
\hline Purposes: To determine the efficacy of bromopride in the prophylaxis of \\
nausea during fluorescein angiography, when compared with a placebo. \\
Methods: The study was a double-masked random clinical trial, between \\
December of 2004 and April of 2005 . Examinations were performed with \\
$20 \%$ intravenous fluorescein sodium in a single dose of $2.5 \mathrm{ml}$. The \\
patients were divided into two groups: group 1, patients who received \\
a 2 ml intravenous dose of $5 \mathrm{mg} / \mathrm{ml}$ bromopride and group 2 , patients who \\
received a 2 ml intravenous dose of $0.9 \%$ sodium chloride (placebo), both \\
20 minutes before the dye injection. Cases of nausea were observed \\
during and after the examination. Results: 352 patients were enrolled, 176 \\
in each group. Cases of nausea were observed in 12 (6.8\%) patients of \\
the bromopride group and in 11 (6.3\%) patients of the placebo group \\
(p<0.829- relative risk=1.05). Conclusion: Bromopride did not prevent \\
the occurrence of nausea in fluorescein angiography, when compared \\
with a placebo.
\end{tabular}

Keywords: Nausea/prevention \& control; Metoclopramide/therapeutic use; Fluorescein angiography; Drug hypersensitivity; Randomized controlled trial [publication type]
Trabalho realizado na Universidade Estadual de Campinas - UNICAMP - Campinas (SP) - Brasil e na Universidade Federal de Pernambuco - UFPE - Recife (PE) - Brasil.

${ }^{1}$ Doutor e Preceptor do Curso de Pós-Graduação em Ciências Médicas da Universidade Estadual de Campinas - UNICAMP - Campinas (SP) - Brasil. Preceptor do Curso de Especialização em Oftalmologia da Universidade Federal de Pernambuco - UFPE - Recife (PE) Brasil.

${ }^{2}$ Médico Residente do Hospital das Clínicas da UFPE Recife (PE) - Brasil.

${ }^{3}$ Médico Residente do Hospital das Clínicas da UFPE Recife (PE) - Brasil.

${ }^{4}$ Médico Residente do Hospital das Clínicas da UFPE Recife (PE) - Brasil.

${ }^{5}$ Médico Residente do Hospital das Clínicas da UFPE Recife (PE) - Brasil.

Endereço para correspondência: Rodrigo Pessoa Cavalcanti Lira. Rua Aquarius, 76 - Apto. 1403 - Recife (PE) CEP 52011-020

E-mail: rodrigopclira@hotmail.com

Recebido para publicação em 17.01.2006

Última versão recebida em 08.06.2006

Aprovação em 10.08.2006

\section{INTRODUCTION}

Fluorescein angiography is a technique used for the interpretation of ocular diseases. It allows sequential visualization of the blood flow simultaneously in the retina, choroid and iris, and it gives diagnostic support to clinical impressions based on alterations in fluid dynamics resulting from ocular disease processes ${ }^{(1-2)}$.

This procedure is considered relatively safe and although numerous adverse reactions have been reported in literature, the most frequent are mild, such as nausea and vomiting ${ }^{(3-5)}$. The incidence of these adverse reactions has varied among the authors $(2 \%-14 \%)^{(6-8)}$.

Nausea and vomiting can occur independently, but they are so strictly associated that it is possible to presume that they are mediated by the same neural path and can be considered a set ${ }^{(9-10)}$. The efficient treatment of nausea and vomiting depends on the correlation with the basic cause. Most pharmacologic therapies are reactive instead of preventive. The benefit of antiemetic agents varies according to the etiology of the symptoms, of the response of the patient to the medication and the occurrence of side effects ${ }^{(9-10)}$.

The dopamine receptors in the stomach seem to mediate the inhibition of the gastric motility that occurs during nausea and vomiting, and these receptors can indicate an action site for the antiemetics antagonists of the dopamine receptor. They also participate in the consequences that result in 
a relaxation of the upper part of the stomach and retardation of the gastric emptiness in response to the gastric distension by food. This forms the basis for the use of dopaminergic antagonists as prokinetic agents ${ }^{(9-10)}$.

Bromopride is an antagonist of dopamine. The main action mechanism results from esophagus gastric duodenal transit acceleration and inhibition of the gastric relaxation determined by dopamine, as well as the increase in tonicity of the inferior sphincter of the esophagus. It also has a central level of antiemetic action in the hypothalamus, acting on D2 receptors ${ }^{(11-12)}$.

Nausea results in discomfort for the patient and makes the capture of images difficult in the initial phase of fluorescein angiography, there being cases of subretinal hemorrhage due to Valsalva maneuver ${ }^{(1,13)}$.

The objective of this study was to determine the efficacy of bromopride in the prophylaxis of nausea during fluorescein angiography, when compared with a placebo.

\section{METHODS}

\section{Patient and medical procedures}

This study was a double-masked random clinical trial carried out at the Federal University of Pernambuco. The medical center's Human Subjects Committee approved the study protocol (protocol 229/2005).

Patients scheduled to undergo fluorescein angiography were recruited between December 2004 and April 2005. Patients were excluded from the study if they were pregnant, or made use of dopaminergics, antihistaminic antagonists, antiemetics, corticosteroids or immunosuppressants. All patients provided a written informed consent before enrollment in the study.

For the examination $20 \%$ fluorescein sodium dye (Ophthal$\operatorname{mos}^{\circledR}$ ) was used at a single $2.5 \mathrm{ml}$ dose, injected into the cubital vein, with a manual infusion rate of approximately $1 \mathrm{ml}$ per second.

For the patients who agreed to participate in the study, the scheduled fluorescein angiography was randomly assigned to one of two groups: 1) to be preceded by a $2 \mathrm{ml}$ intravenous dose of $5 \mathrm{mg} / \mathrm{ml}$ bromopride or 2) to be preceded by a $2 \mathrm{ml}$ intravenous dose of $0.9 \%$ sodium chloride (placebo), both 20 minutes before the dye injection. Randomization was performed in blocks of four. Patients were randomly assigned to one of the two study groups until two patients had been assigned to each one of the two groups, completing the block of four. Randomization was performed by computer at the time of enrollment.

The syringes with bromopride or saline solution were prepared by a nursing technician, before the procedure, and identified by a record number for posterior evaluation of the results. It was not possible to visually distinguish the content from the syringe; thus, the doctors and the patients did not know which substance was being applied. Mean age, sex, prevalence of diabetes and arterial hypertension of both groups were compared with the purpose to know if the groups were well balanced. Diabetes and arterial hypertension were selected because they are the most prevalent coexisting illnesses in fluorescein angiography patients ${ }^{(14-15)}$.

\section{Data collection}

The data had been collected through a specific file, which contained history and physical examination of the patient, filled in by the anesthetist at the moment of clinical evaluation. The definition of nausea used in the study was a vague, intensely disagreeable sensation of sickness or queasiness that may or may not be followed by vomiting. Nausea occurring during the angiography had been registered in a file of protocol by the ophthalmologist. Nausea occurring subsequently was collected by a standardized telephone interview of the patient conducted by the study coordinator twelve hours after the examination.

\section{Sample size and statistical analysis}

A minimum sample of 340 patients (170 per group) was planned. Assuming a 7\% incidence of nausea in the placebo group, this sample would allow $80 \%$ power of being able to detect a difference as small as $6.5 \%$ in the bromopride group. As a parameter of central trend and dispersion for the data, means and standard deviation (SD) had been determined. Tests were made to detect differences between variables, using chi-square test and relative risk (RR) for categorical variables, and $t$ test for quantitative variables. The results of this analysis were considered significant if $p$ value was less than 0.05 .

\section{RESULTS}

We enrolled 352 patients scheduled to undergo fluorescein angiography between December 2003 and April 2004. The sample consisted of 176 patients assigned to each group. The two groups were well balanced in terms of age, with a mean age of 57.2 years ( $\mathrm{SD}=11.7$ years) in the bromopride group and 58.6 years $(\mathrm{SD}=14.4$ years $)$ in the placebo group $(\mathrm{p}=0.398)$. The groups were also well balanced with respect to sex and prevalence of diabetes and arterial hypertension (Table 1$)$.

Nausea was observed in 12 (6.8\%) patients of the bromopride group and in $11(6.3 \%)$ patients of the placebo group $(p<0.829-\mathrm{RR}=1.05[0.70<\mathrm{RR}<1.57])$ (Table 2). All cases of nausea occurred during the angiography.

\begin{tabular}{|c|c|c|c|}
\hline Characteristics & $\begin{array}{c}\text { Bromopride } \\
(n=176)\end{array}$ & $\begin{array}{l}\text { Placebo } \\
(n=176)\end{array}$ & p \\
\hline Age (years) & $57.2 \pm 11.7$ & $58.6 \pm 14.4$ & $0.398^{*}$ \\
\hline \multicolumn{4}{|c|}{ Number of patients (\%) } \\
\hline Female & 99 (56.2) & $93(52.8)$ & $0.520^{\dagger}$ \\
\hline Arterial hypertension & $77(43.7)$ & $73(41.5)$ & $0.666^{\dagger}$ \\
\hline Diabetes & $65(36.9)$ & $69(39.2)$ & $0.660^{\dagger}$ \\
\hline
\end{tabular}




\begin{tabular}{|c|c|c|c|c|c|c|}
\hline \multirow[b]{3}{*}{ Nausea } & \multicolumn{4}{|c|}{ Medication } & \multirow[b]{3}{*}{$\mathbf{p}$} & \multirow[b]{3}{*}{$\mathbf{R R}^{*}$} \\
\hline & \multicolumn{2}{|c|}{$\begin{array}{c}\text { Bromopride } \\
(n=176) \\
\end{array}$} & \multicolumn{2}{|c|}{$\begin{array}{l}\text { Placebo } \\
(n=176) \\
\end{array}$} & & \\
\hline & $\mathbf{n}$ & $\%$ & $n$ & $\%$ & & \\
\hline Present & 12 & 6,8 & 11 & 6,3 & $0,83^{\dagger}$ & 1,05 \\
\hline Absentee & 164 & 93,2 & 165 & 93,7 & & $(0,70<R R<1,57)$ \\
\hline
\end{tabular}

\section{DISCUSSION}

The frequency of nausea in the present study was $6.53 \%$, which is in accordance with the literature ${ }^{(6-8)}$. The pathophysiology involves the activation of chemoreceptor of the vomiting nervous center, located in the postrema area, posterior region of the fourth ventricle, alternatively as well as through other stronger influences of the central nervous system (for example, limbic system) that function as primary detectors of the emetic stimulation and induce vomiting through integration with the postrema area, vagal nerve or vestibular system ${ }^{(9-10,12,16)}$.

Random clinical trials were carried out evaluating the influence of the concentration and the temperature of the dye in the prophylaxis of nausea in fluorescein angiography. A difference in the incidence of nausea between $10 \%$ and $25 \%$ concentrations of this dye was not observed and the $25 \%$ solution resulted in examinations of better quality ${ }^{(17)}$. In addition, a reduction of the incidence of nausea with the heating of the contrast was not observed ${ }^{(18)}$.

Only two random clinical trials exist to discuss the use of medicines for nausea and vomiting prophylaxis in fluorescein angiography, where granisetron and metoclopramide have respectively been used ${ }^{(19-20)}$.

Some authors carried out a study with 120 patients comparing oral granisetron and a placebo and they observed $3(5 \%)$ cases of vomiting in the placebo group and none with this medication. Despite the small sample, these authors suggested granisetron would be indicated for vomiting prophylaxis in fluorescein angiography ${ }^{(19)}$. Granisetron is a selective antagonist of the 5- $\mathrm{HT}_{3}$ receptor of 5-hydroxytryptamine and is usually indicated for nausea prophylaxis associated with a cytostatic therapy. However its use is associated with a larger incidence of hepatocellular neoplasia ${ }^{(21)}$.

Some authors carried out a study with 100 patients comparing intravenous metoclopramide and a placebo and observed $11(22 \%)$ cases of nausea or vomiting in the placebo group and $3(6 \%)$ with this medication ${ }^{(20)}$. This study presented the limitation that the incidence of nausea in the placebo group was higher than that observed in literature ${ }^{(6-8)}$, a fact that was explained by the authors as a result of the used methodology where the patient was stimulated to communicate any evidence of nausea $^{(20)}$. Metoclopramide constitutes the archetype of selective antagonists of dopamine, called substitute benzamide and has a powerful peripheral cholinergic effect that intensifies gastric emptiness. However, the collateral neurological effects are frequent, as well as muscular spasms, trembling, Parkinsonism and visual disturbance ${ }^{(10,12,19)}$. The main advantage of bromopride in relation to metoclopramide is the lower incidence of neurological side effect, mainly extrapyramidal reactions ${ }^{(11)}$.

Bromopride is used at a large scale because of its effectiveness in the treatment of nausea and vomiting, being considered safe also in children, pregnant women and elderly people $^{(22-24)}$. Its use in the prophylaxis of nausea induced by medicines was also studied. A research on women who developed symptoms of digestive intolerance caused by medicines demonstrated that bromopride was efficient in the prophylaxis of these symptoms ${ }^{(25)}$.

In this study, the use of the bromopride before the fluorescein angiography did not decrease the incidence of nausea. A possible explanation for the inefficacy of the bromopride in the prophylaxis of nausea would be the insufficient time for the drug to start acting, however, after intravenous administration, drug bioavailability is immediate and a phase of initial distribution occurs during a short period of time (5-10 minutes) and the half-life is 3 hours $^{(11)}$.

The results suggested that the use of bromopride as prophylaxis for nausea in fluorescein angiography is not a procedure that should be stimulated. However, it is not possible to discard its utility in the treatment of already symptomatic patients. Further studies will be necessary to confirm these findings.

\section{CONCLUSION}

In this study, bromopride did not prevent the occurrence of nausea in fluorescein angiography, when compared with a placebo.

\section{RESUMO}

Objetivos: Determinar a eficiência da bromoprida na profilaxia de náuseas na angiofluoresceinografia, quando comparada a um placebo. Métodos: O estudo foi um ensaio clínico aleatório duplo-mascarado, entre dezembro de 2004 e abril de 2005. Os exames foram realizados com fluoresceína sódica a $20 \%$ intravenosa em dose única de $2,5 \mathrm{ml}$. Os pacientes foram divididos em dois grupos: grupo 1, pacientes que receberam $10 \mathrm{mg} / 2 \mathrm{ml}$ de bromoprida via intravenosa e o grupo 2, pacientes que receberam uma dose $2 \mathrm{ml}$ de cloreto de sódio a $0,9 \%$ (placebo), ambos 20 minutos antes da injeção do contraste. Foram registrados os casos de náusea durante e após o exame. Resultados: Foram selecionados 352 pacientes, 176 em cada grupo. Foram registrados casos de náusea em $12(6,8 \%)$ pacientes do grupo da bromoprida e $11(6,3 \%)$ pacientes do grupo placebo $(\mathrm{p}<0,829$ - risco relativo=1,09). Conclusão: Neste estudo a bromoprida não preveniu a ocorrência de náuseas na angiofluoresceinografia, quando comparada a um placebo. 
Descritores: Náusea/prevenção \& controle; Metoclopramida/ uso terapêutico; Angiofluoresceinografia; Hipersensibilidade a drogas; Ensaio clínico controlado aleatório [tipo de publicação]

\section{REFERENCES}

1. Berkow JW, Flower RW, Orth DH, Kelley JS. Fluorescein and indocyanine green angiography, 2nd ed. San Francisco: The Foundation of the American Academy of Ophthalmology; 1997.

2. Blacharski PA. Twenty-five years of fluorescein angiography. Arch Ophthalmol. 1985;103(9):1301-2.

3. Karhunen U, Raitta C, Kala R. Adverse reactions to fluorescein angiography Acta Ophthalmol (Copenh). 1986;64(3):282-6.

4. Kwiterovich KA, Maguire MG, Murphy RP, Schachat AP, Bressler NM, Bressler SB, Fine SL. Frequency of adverse systemic reactions after fluorescein angiography. Results of a prospective study. Ophthalmology. 1991;98(7):1139-42.

5. Stein MR, Parker CW. Reactions following intravenous fluorescein. Am J Ophthalmol. 1971;72(5):861-8.

6. Lepri A, Salvini R, Rizzo L, Cetica P, Grechi S, Di Filippo A, Conti M, Benvenuti S, Novelli GP. [Accident during retinal fluorescein angiography] Minerva Anestesiol. 1997;63(4):133-40. Italian.

7. Yannuzzi LA, Rohrer KT, Tindel LJ, Sobel RS, Costanza MA, Shields W, Zang E. Fluorescein angiography complication survey. Ophthalmology. 1986 May;93(5):611-7.

8. Lacava AC, Leal EB, Caballero JC, Medeiros OA. Angiografia fluoresceínica e suas complicações, relato de 1 caso de óbito. Rev Bras Oftalmol. 1996;55 (1):59-62.

9. Brunton LL. Fármacos que afetam a motilidade e o fluxo de água gastrointestinais. In: Gilman AG, Goodman AG. Goodman \& Gilman: As bases farmacológicas da terapêutica. 9a ed. Rio de Janeiro: Guanabara-Koogan, 1996;683-8.

10. Champion MC. Nausea and vomiting. In: Thomson ABR, Shaffer EA, editors. First principles of gastroenterology. 3rd ed. Vancouver: University of Toronto Press; 2000. p.12-4.
11. Libbs Farmacêutica. Bromopride. São Paulo; 2003. [monografia].

12. Pontes JF, Marchese MA, Magalhães MBC. Farmacologia e tratamento das doenças do estômago e duodeno. In: Silva P. Farmacologia. 6a ed. Rio de Janeiro: Guanabara-Koogan; 2002. p.902-5.

13. Antoszyk AN, de Juan E Jr, Landers MB. Subretinal hemorrhage during fluorescein angiography. Am J Ophthalmol. 1987;103(1):111-2.

14. Veloso JCB, Ventura AG, Escarião PHG, Leite Neto AQ, Dias S. Angiofluoresceinografia em serviço de referência: freqüência diagnóstica. An Fac Med Univ Fed Pernamb. 2001;46(1):45-7

15. Lucena DR, Siqueira RC. Os dez mais freqüentes diagnósticos angiofluoresceinográficos de um serviço de referência em retina e vítreo. Rev Bras Oftalmol. 2000;59(8):594-6.

16. Andrews PL. Physiology of nausea and vomiting. Br J Anaesth. 1992;69(7 Suppl 1):2S-19S.

17. Justice J Jr, Paton D, Beyrer CR, Seddon GG. Clinical comparison of 10 percent and 25 percent intravenous sodium fluorescein solutions. Arch Ophthalmol. 1977;95(11):2015-6.

18. Lee LR, Hainsworth DP, Hamm CW, Madsen RW. Temperature effect on nausea during fluorescein angiography. Ophthalmology. 2001;108(7):1193-5.

19. Mattioli V, Calo A, Pisoni G, Ancona G, Zollino D, Brunetti P. Oral granisetron as prophylaxis for nausea and vomiting during fluorescein angiography. A multicentre, double-blind, randomised, parallel group, placebo-controlled study. Minerva Anestesiol. 1998;64(12):553-61.

20. Brown RE Jr, Sabates R, Drew SJ. Metoclopramide as prophylaxis for nausea and vomiting induced by fluorescein. Arch Ophthalmol. 1987;105(5):658-9.

21. Laboratório Roche. Kytril comprimidos (cloridato de granisetrona) [texto na Internet]. São Paulo; Laboratório Roche. [citado 2005 Ago 21]. Disponível em: http://www.roche.com.br/NR/rdonlyres/741A3266-ABA6-4104-A0D03AC48B0B7546/913/Kitril_Comp.pdf.

22. Magano LA. O emprego do bromopride como antiemético em casos de emergência. Folha Méd. 1978;77:101-6.

23. Vialatte J. Experiência clínica em crianças com o bromopride-Val 1308. Folha Med. 1981;83(1):79-81.

24. Araújo JR. Avaliação do bromopride nas náuseas e vômitos da gestação. J Bras Ginecol. 1981:91(4):283-5.

25. Condé F. Bromopride na antagonização de náuseas e vômitos induzidos por fármacos. J Bras Ginecol. 1978;85(3):149-52.

\section{*Participação neste evento conta 20 pontos para a revalidação do título de especialista em ofitalmologia}
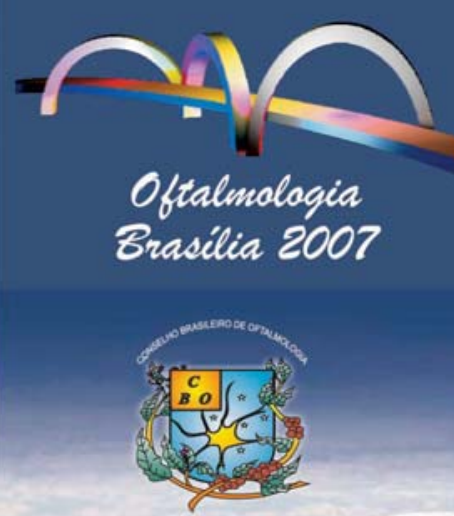

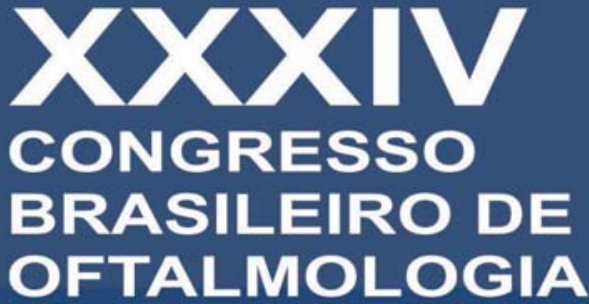

3 a 6 de setembro de 2007

Centro de Convenções

Brasília - DF - Brasil

\section{COMISSÃO EXECUTIVA}

PRESIDENTE DE HONRA Harley Edison A. Bicas (SP)

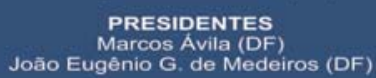

Eào Eugenio G. de Medeiros VICE-PRESIDENTES
Eduardo Almeida de Menezes (DF) Procópio Miguel dos Santos (DF) SECRETARIO GERAL Alipio de Sousa Neto (DF) TESOUREIRO Marco Antônio Vieira Paschoal (DF) José Domingos Costa (DF)
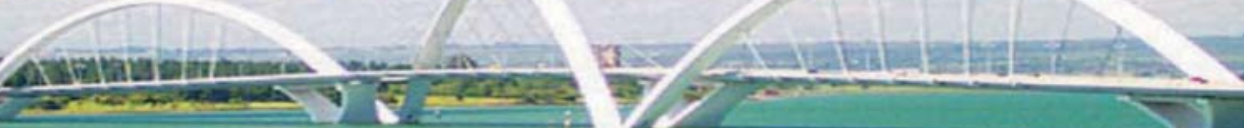

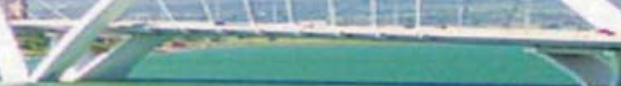

INFORMAÇÕES:

XXXIV CONGRESSO BRASILEIRO DE OFTALMOLOGIA

SEPS 714/914 - ED. TALENTO, SALA 422 - ASA SUL - CEP 70390-145 - BRASÍLIA - DF - BRASIL

TELS.: (61) 3346-6971 ou (62) 3251-0500/3252-5570

e-mail: cbo2007@cbo.com.br

Visite nosso site:

www.cbo2007.com.br 